\title{
Protein synthesis rates in colon and liver: stimulation by gastrointestinal pathologies
}

\author{
S D Heys, K G M Park, M A McNurlan, R A Keenan, J D B Miller, O Eremin, P J Garlick
}

\begin{abstract}
Rates of protein synthesis in vivo in normal and pathological tissues of the gastrointestinal tract, were measured using the 'flooding dose' technique with the stable isotope $L-\left[1-{ }^{13} \mathrm{C}\right]$ leucine. The rate of protein synthesis in normal colonic mucosa was $9.4(1.2) \%$ (mean (SEM)) per day but was significantly raised in benign and malignant colorectal tumour tissue, and in colonic mucosa from patients with inflammatory bowel disease $(p<0 \cdot 001)$. Furthermore, the rate of protein synthesis was significantly greater in benign colorectal tumour tissue, $36.7(2 \cdot 5) \%$ per day, than that in either malignant tumour tissue, 21.7 (1.9)\% per day, or in inflammatory bowel disease mucosa, $24 \cdot 7(2 \cdot 5) \%$ per day (means (SEM) $\mathbf{p}<0.001$ ). Liver protein synthesis rates were also measured in separate groups of patients with benign disease of the gastrointestinal tract, in patients with colorectal carcinoma, and in patients with inflammatory bowel disease. The fractional rate of liver protein synthesis was $20.7(1.9) \%$ per day in patients with benign disease and $23 \cdot 1(1 \cdot 6) \%$ per day in patients with colorectal cancer. In patients with inflammatory bowel disease, however, liver protein synthesis was significantly increased to 35.4 $(2 \cdot 3) \%$ per day (means $($ SEM) $\mathbf{p}<0 \cdot 01$ ).
\end{abstract}

The development of weight loss and malnutrition, with a concomitant loss of body nitrogen, reduced nitrogen intake and reduction in lean body mass, are well recognised findings in patients with benign or malignant disease of the colon. ${ }^{12}$ With inflammatory bowel disease, the loss of protein through the gastrointestinal tract is also a contributory factor. ${ }^{23}$ Previous investigations of protein metabolism in these clinical disorders have centred on measurements of whole body protein turnover. In the presence of a malignant tumour - for example, lung or colon, increases in whole body protein synthesis and breakdown have been reported, ${ }^{45}$ although other studies have detected no change. ${ }^{67}$ Rises in whole body turnover rates have also been seen in patients with inflammatory bowel disease. Moreover, the increased rate of protein synthesis and breakdown correlated with the severity of the disease activity, as assessed from the patients erythrocyte sedimentation rates. ${ }^{8}$

These studies of whole body protein metabolism, however, simply reflect an average of events occurring in all individual tissues. In the presence of malignancy it is known that different tissues can respond in different ways. For example, Pain et $a l^{9}$ have shown that in experimental tumour-bearing animals, protein synthesis was decreased in skeletal muscle but increased in liver when compared with nontumour bearing controls. Similarly in man, in patients with bronchial carcinoma there was a decrease in skeletal muscle protein synthesis but no change in whole body protein synthesis, when compared with control patients without malignant disease. ${ }^{10}$ Measurement of protein synthesis in individual tissues is therefore advantageous when further investigating these abnormalities in protein metabolism, but in the past this has usually required animal studies.

Tumour protein synthesis has been previously measured in man by constant infusion of $\left[{ }^{5} \mathrm{~N}\right]$ glycine or $\left[{ }^{14} \mathrm{C}\right]$ leucine, ${ }^{11-13}$ In order to calculate rates of protein synthesis accurately, however, it is necessary to correctly measure the isotopic enrichment of the precursor free amino acid. Compartmentation of free amino acid pools results in different isotopic enrichment in the intra and extracellular pools when tracer amounts of label are given. Moreover, the enrichment of neither of these alternatives may be representative of that of the true precursor, so that erroneous rates of protein synthesis may result. ${ }^{1+}$ The problem was minimised in measurements on cells and tissues in vitro, however, and in small animals in vivo, by the 'flooding dose' technique, in which all amino acid pools are rapidly equilibrated to similar enrichments.

We have further developed the 'flooding dose' technique for measurement of tissue protein synthesis in normal and pathological tissues in man, in vivo, ${ }^{15-17}$ and have now applied it to the study of normal and diseased colorectal tissue. Additional measurements were also made of liver protein synthesis to determine whether the presence of gastrointestinal pathology affected protein synthesis in this tissue which was not directly affected by the disease.

\section{Methods}

\section{PATIENTS}

This study was performed in the Grampian group of hospitals and was approved by the Joint Ethical Committee of the University of Aberdeen and the Grampian Health Board, with all patients giving informed consent.

STUDY 1

The patients studied were both male and female who had been admitted to hospital for elective surgery. Patients with colorectal tumours (benign and malignant) and inflammatory bowel disease underwent standard bowel preparation which consisted of a low residue diet for two days Aberdeen Royal Infirmary, Foresterhill, Aberdeen AB9 2ZD.

Accepted for publication 11 November 1991 
and Picolax (Nordic Pharmaceuticals, Feltham, Middlesex) on the day before surgery. Patients undergoing haemorrhoidectomy received only phosphate enemas on the day before surgery.

Details of patients are given in Table I and they were divided into four groups: group a: colorectal carcinoma; group b: benign colorectal tumours - that is, tubulovillous adenomas; group c: inflammatory bowel disease (five patients had ulcerative colitis and one patient had Crohns disease, with stool frequencies ranging from four to six motions per day; all patients had diffuse pan-colitis and were histologically reported as 'moderate active chronic colitis'; and group d: haemorrhoidectomy. All patients were fasted before surgery. Measurements of protein synthesis in biopsies of colorectal tissue were made. The tissues sampled were malignant colorectal tumour tissue (group a), benign colorectal tumour tissue (group b), rectal mucosa from patients with inflammatory bowel disease (group c), and healthy rectal mucosa from those patients undergoing haemorrhoidectomy (group d).

\section{STUDY 2}

The patients studied were both male and female and their details are shown in Table II. They had been admitted for the surgical treatment of the following conditions: group e: benign disease (comprising patients with benign colorectal tumours (two), plus those with chronic cholecystitis; group f: inflammatory bowel disease (all patients had moderately active ulcerative colitis with diffuse involvement of the whole colon, but no evidence at laparotomy or on liver function tests of hepatic damage); group g: colorectal carcinoma. Liver protein synthesis rates were measured, at the time of surgery, as described below.

\section{MEASUREMENT OF PROTEIN SYNTHESIS}

In study 1 , protein synthesis was determined by the 'flooding dose' technique, as described pre-

TABLE I Clinical details of patient groups in whom protein synthesis was measured in normal and pathological tissues

\begin{tabular}{llll}
\hline $\begin{array}{l}\text { Patient group } \\
(n)\end{array}$ & $\begin{array}{l}\text { Age } \\
(y r)\end{array}$ & $\begin{array}{l}\text { Body mass } \\
\text { index }\left(\mathrm{kg} / \mathrm{m}^{2}\right)\end{array}$ & $\begin{array}{l}\text { Serum albumin } \\
(\mathrm{g} / \mathrm{l})\end{array}$ \\
\hline $\begin{array}{l}\text { Normal mucosa (5) } \\
\text { Tubulovillous }\end{array}$ & $49(10)$ & $23(1)$ & $41(1)$ \\
$\begin{array}{l}\text { adenomas (6) } \\
\text { Inflammatory bowel } \\
\quad \text { disease (6) }\end{array}$ & $67(7)$ & $23(1)$ & $42(0 \cdot 6)$ \\
$\begin{array}{l}\text { Colorectal cancer (6) } \\
\text { (3) }\end{array}$ & $71(4)$ & $21(1)$ & $39(1)$ \\
\hline
\end{tabular}

Values shown are means (SEM)

TABLE II Clinical details of patients in whom liver protein synthesis was measured

\begin{tabular}{llll}
\hline $\begin{array}{l}\text { Patient group } \\
(\mathrm{n})\end{array}$ & $\begin{array}{l}\text { Age } \\
(\mathrm{yr})\end{array}$ & $\begin{array}{l}\text { Body mass } \\
\text { index }\left(\mathrm{kg} / \mathrm{m}^{2}\right)\end{array}$ & $\begin{array}{l}\text { Serum albumin } \\
(\mathrm{g} / \mathrm{l})\end{array}$ \\
\hline $\begin{array}{l}\text { Benign disease } \\
\text { Inflammatory bowel }\end{array}$ & $58(4)$ & $22(0 \cdot 5)$ & $39(1)$ \\
$\quad \begin{array}{l}\text { disease }(4) \\
\text { Colorectal cancer }(5)\end{array}$ & $\begin{array}{l}40(10) \\
\text { 71(2) }\end{array}$ & $21(0 \cdot 6)$ & $36(1)$ \\
\hline
\end{tabular}

Values shown are means $(\mathrm{SEM})^{\star}$, patients in the benign disease group comprised three patients with chronic cholecystitis and two with benign colonic tumours. viously. ${ }^{15}{ }^{16} \mathrm{~A}$ bolus of $\mathrm{L}-\left[1-{ }^{13} \mathrm{C}\right] \mathrm{leucine}(4 \mathrm{~g} / 70 \mathrm{~kg}$ body weight, 19.4 atom \%) was given at a constant rate in $200 \mathrm{ml} 0.9 \%$ saline over 10 minutes. Venous blood samples $(5 \mathrm{ml})$ were taken at $10,20,30,60$, and 90 minutes after the start of injection of isotope for measurement of the isotopic enrichment of plasma free leucine. After allowing between 45 and 90 minutes for incorporation of labelled amino acid into protein, anaesthesia was induced and biopsies of rectal mucosa or tumour were taken immediately, through a sigmoidoscope (therefore the patient was anesthetised for only five minutes of the 45-90 minute period available for incorporation of isotope). The biopsies were immediately frozen in liquid nitrogen and stored at $-20^{\circ} \mathrm{C}$ until analysed.

In study 2, the same 'flooding dose' procedure was carried out except that an operative liver biopsy, approximately $200 \mathrm{mg}$, was taken immediately after the abdomen had been opened. This biopsy was taken from the anterior surface of the right lobe of the liver. There was no evidence of hepatic metastases in those patients with colorectal carcinoma at the time of the study, and serum bilirubin, and aspartate aminotransferase, alkaline phosphatase and gammaglutamyltransferase activities were normal.

\section{ANAESTHETIC TECHNIQUE}

A standard anaesthetic regimen was used in all patients. Anaesthesia was induced with suxamethonium and propofol, and maintained using a combination of nitrous oxide, oxygen and isoflurane.

\section{SAMPLE PREPARATION}

The free and protein bound leucine in the tissue biopsies were separated by pulverising the frozen tissue, homogenising in $0.2 \mathrm{M} \mathrm{HClO}_{4}$ at $4^{\circ} \mathrm{C}$ and centrifuging at $2800 \mathrm{~g}$ for 20 minutes. The supernatant containing the free leucine was neutralised with $1 \mathrm{M} \mathrm{KOH}$ at $4^{\circ} \mathrm{C}$ and centrifuged to remove excess $\mathrm{KClO}_{4}$. This supernatant was used for measurement of isotopic enrichment of free leucine. The protein precipitate was washed with $\mathrm{HClO}_{4}$, dissolved in $0.3 \mathrm{M} \mathrm{NaOH}$ at $37^{\circ} \mathrm{C}$ for one hour and then reprecipitated with $2 \mathrm{M} \mathrm{HClO}_{4}$. The protein pellet was washed again with $0.2 \mathrm{M} \mathrm{HClO}_{4}$, before hydrolysing in $6 \mathrm{M}$ hydrochloric acid for 24 hours at $110^{\circ} \mathrm{C}$. After hydrolysis, the hydrochloric acid was removed by evaporation in vacuo, and the remaining sample used for the measurement of isotopic enrichment of leucine in protein.

Preparation of plasma for determination of isotopic enrichment of free leucine was performed as described previously. ${ }^{15}$

\section{MEASUREMENT OF ${ }^{13} \mathrm{C}$ ENRICHMENTS}

\section{Plasma and tissue free leucine}

The enrichment of plasma free leucine was measured using a VG 12-250 quadrupole gas chromatograph mass spectrometer (VG, Masslab, Manchester, UK), after conversion to 


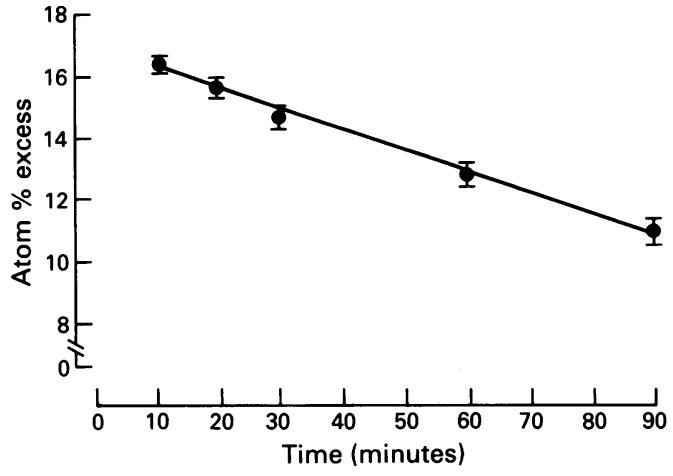

Figure 1: Time course for the fall in plasma free leucine enrichment following administration of $L-\left[1-{ }^{13} C\right]$ leucine. Values shown are means (SEM).

the tertiary butyldimethylsilyl derivative. The ion peaks at $\mathrm{m} / \mathrm{z} 302$ and 303 were monitored under electron impact and selective ion recording conditions. ${ }^{18}$

The enrichment of tissue free leucine was also measured using GCMS after conversion of leucine to the $\mathrm{N}$-butyl heptafluorobutyryl isobutyl derivative. ${ }^{19}$ Chemical ionization, with methane as the reactant gas, and selective ion recording of the ion peaks at $\mathrm{m} / \mathrm{z} 363$ and 364 was used.

\section{Protein bound leucine}

Leucine was separated from other amino acids in the protein hydrolysate by preparative ion exchange chromatography. Leucine- $\mathrm{CO}_{2}$ was liberated by reaction with ninhydrin at $\mathrm{pH} 2 \cdot 2,{ }^{20}$ and its enrichment measured along the lines described by Halliday and Reid ${ }^{21}$ using a gas isotope ratio mass spectrometer, SIRA 12 (VG Isogas, Middlewhich, Cheshire, UK).

\section{CALCULATIONS}

The fractional rate of protein synthesis in the tissue was calculated from the formula described by McNurlan $e t a l^{22}$;

$$
k_{s}=\left(p_{(t)}-P_{(0)}\right) \times 100 / A
$$

where, $k_{s}$ is the fractional rate of protein synthesis (\% per day), $P_{(0)}$ and $P_{(t)}$ are the enrichments of leucine in tissue protein at the beginning and end of the incorporation period (atom \%) and $\mathrm{A}$ is the area under the curve for precursor enrichment (atom $\%$ excess $\times$ time in days), assuming a linear increase from 0 to the measured value at 10 minutes. $P_{(0)}$ was taken to equal the enrichment of a zero time sample of plasma proteins. ${ }^{23}$

\section{STATISTICAL ANALYSIS}

The significance of differences between means was assessed using the Mann Whitney U test.

\section{Results}

The clinical details of the patients studied are shown in Tables I and II. The mean age of patients in the colorectal cancer and benign colorectal tumour groups was higher than that of the inflammatory bowel and normal rectal

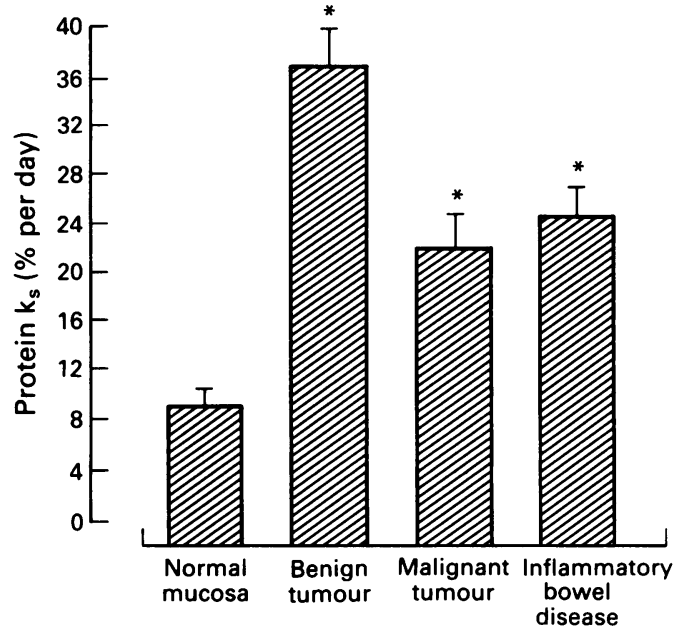

Figure 2: Rates of protein synthesis in normal colorectal mucosa, mucosa from patients with inflammatory bowel disease (IBD), benign tumours of the rectum and in malignan colorectal tumours. (Values shown are means (SEM), ${ }^{\star} p<0.001$ compared with normal colorectal mucosa.

mucosa groups, as would be expected from the age distributions of surgery for these different pathologies. The nutritional status of all groups, however, as assessed by body mass index (body weight/height ${ }^{2}$ ) was comparable.

\section{PLASMA AND BIOPSY FREE LEUCINE ${ }^{13} \mathrm{C}$} ENRICHMENTS

The time course of the plasma free leucine enrichment after the 'flooding dose' (Fig 1), showed peak enrichment immediately after the leucine infusion had finished followed by a linear fall in all subjects.

One of the criteria for 'flooding' is that different amino acid pools should reach similar enrichments. In order to determine if this had occurred, the biopsy free leucine enrichments were measured and compared with the plasma free leucine enrichment at the time of taking the biopsy. This was expressed as a ratio of biopsy/ plasma free leucine enrichment. These ratios were $0.92(0.03), 0.88(0.02), 0.90(0.02)$, and $0.85(0.02)$ (means (SEM)) for normal mucosa, benign tumour, malignant tumour and inflamed mucosa, respectively. In the liver biopsies the ratios were $0.84(0.02), 0.86(0.04)$, and 0.81 $(0.05)$ for benign gastrointestinal disease, colorectal cancer and inflammatory bowel disease groups of patients respectively.

\section{TISSUE PROTEIN SYNTHESIS RATES}

The fractional rate of protein synthesis in normal colonic mucosa was $9.4(1 \cdot 2) \%$ per day (mean (SEM)), but was significantly raised in all the pathological conditions studied $(\mathrm{p}<0.001)$. The values were, $36.7(2.5) \%$ per day in benign colorectal tumour tissue, $21.7(1.9) \%$ per day in malignant colorectal tissue, and $24 \cdot 7(2 \cdot 5) \%$ per day in rectal mucosa from patients with inflammatory bowel disease (Fig 2).

Liver fractional protein synthetic rates in the three groups of patients are shown in Figure 3. The values were $20.7(1.9) \%$ per day in patients in the benign group, and $23 \cdot 1(1 \cdot 6) \%$ per day in 


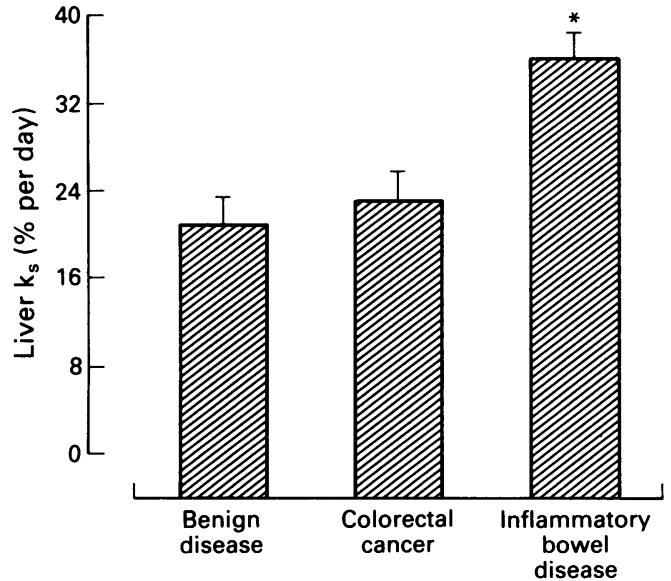

Figure 3: Rates of liver protein synthesis in patients with inflammatory bowel disease $(I B D)$, colorectal cancer and a control group with benign disease. (Values shown are mean $(S E M), p<0.01$ compared with colorectal cancer and benign groups of patients.)

patients with colorectal cancer. In the patients with inflammatory bowel disease, however, liver protein synthesis was significantly raised to $35 \cdot 4$ $(2 \cdot 3) \% /$ day $(\mathrm{p}<0 \cdot 01)$

\section{Discussion}

The development and application of the 'flooding dose' technique to the measurement of protein synthesis is rapidly turning over tissues, such as tumour tissue, has facilitated a further evaluation of rates of protein synthesis in diseased tissues derived from patients with gastrointestinal pathology. In order to obtain 'baseline rates' for colonic mucosa, a group of patients who were undergoing a haemorrhoidectomy (all without evidence of colorectal tumour on barium enema and sigmoidoscopic examinations) consented to undergo measurement of protein synthesis. The rate of protein synthesis in disease free colonic mucosa from non-tumour bearing patients has not been reported previously, although Stein et $a l^{11}$ did measure protein synthesis in the macroscopically 'normal' colonic mucosa of patients with colorectal cancer. These workers reported a wide range of rates, from 2 to $26 \%$ per day, with a mean (SEM) of $9 \cdot 4(2.5) \%$ per day (seven). This is similar to the rate for normal mucosa obtained here, but with more interindividual variation. Disease free mucosa from cancer patients was not studied in the present investigation because of the technical difficulty of taking a second biopsy after the tumour had been removed.

The protein synthesis rate in localised malignant colorectal tumours of $21 \cdot 7(1 \cdot 9)$ per day (mean (SEM)) is similar to that reported previously. ${ }^{16}$ The rate in benign colorectal tumours, however, has not been previously documented. The value obtained in these benign tubulovillous adenomas was significantly raised relative to both normal and malignant tissues. The reasons for this are unclear, but there are two possible explanations. It is known that approximately $30 \%$ of benign tumours will become 'invasive' and therefore it is possible that an increase in protein synthesis, which would be needed for further growth, might herald the development of the malignant phenotype and invasion by the tumour cells. The histological appearances were all benign, however, and showed changes of mild or moderate dysplasia only, with no evidence of malignant change or invasion into the underlying tissues. Furthermore, experimental studies have investigated cell kinetics in normal mucosa and in benign and malignant tumours of the human colon by labelling with bromodeoxyuridine. ${ }^{2+}$ These studies have shown that the labelling index was significantly lower in normal mucosa than in benign and malignant tumours, and that of malignant tumours was significantly greater than that in benign tumours. In addition, the labelling index of benign tumours with low grade dysplasia was significantly lower than that in those with high grade dysplasia. It is therefore unlikely that the increased protein synthesis in benign tumours represents a metabolic marker for the malignant phenotype and more aggressive tumour. A further possible explanation, however, lies in the well recognised production of large amounts of mucoprotein by villous tumours of the rectum. It may be that the increased protein synthesis by these tumours represents an increased production of secretory mucoprotein, the synthesis of which has been measured, in addition to the structural proteins, by the 'flooding dose' method.

Previous investigations of protein metabolism in patients with inflammatory bowel disease, like those in malignancy, have centred on whole body measurements. Powell-Tuck et $a l^{8}$ measured whole body protein metabolism in 19 patients with ulcerative colitis, while they were receiving enteral or intravenous nutrition. It was found that increases in protein synthesis and breakdown could be correlated with the progression of disease severity, as judged by erythrocyte sedimentation rate and clinical symptoms. No measurements of protein synthesis in individual tissues or intestinal mucosa were carried out in these studies, however. The contribution, therefore, of the pathological colon to this increased whole body protein synthesis and breakdown was unknown. Moreover, there are no data in healthy man regarding the contribution that the colonic mucosa makes to whole body protein synthesis. Studies in experimental animals have shown that in the rat, the fractional rate of protein synthesis in normal colonic mucosa is $62 \%$ per day, but this only contributes $2 \cdot 6 \%$ of whole body protein synthesis. ${ }^{25}$ If a comparable relationship between protein synthesis in colonic mucosa and in the whole body existed in man, then colonic protein synthesis would have to increase by a factor of 80 to account for a doubling of whole body protein synthesis. ${ }^{26} \mathrm{As}$ the increase in synthesis in rectal mucosa from patients with inflammatory bowel disease was very much less than this, the increase in whole body protein turnover in such patients is not solely because of an increase in colonic protein synthesis.

Synthesis of proteins by the human liver, both structural and secretory, is of interest and relevance in patients because of the hepatic involvement in the acute phase response. Indeed, animal studies have shown that the presence of a tumour results in increased hepatic 
protein synthesis. ${ }^{9}$ Before measuring liver protein synthesis with a 'flooding dose', it was necessary to confirm that the $\left[{ }^{13} \mathrm{C}\right]$ leucine enrichments in the liver tissue were comparable with those of plasma, after injection of isotope. The ratios of liver to plasma free leucine enrichment at the end of the measurement period were lower than the value of $95 \%$ seen in muscle with the same protocol, ${ }^{15}$ which compares with $50 \%{ }^{27}$ to $80 \%{ }^{17}$ in muscle when $\left[{ }^{13} \mathrm{C}\right]$ leucine is infused as a tracer dose. Our previous studies have shown that at 10 minutes and 30 minutes after a flooding dose of $\left[{ }^{13} \mathrm{C}\right]$ leucine the enrichment of liver free leucine was $102 \%$ and $95 \%$ respectively of plasma values, falling to $81 \%$ at 90 minutes. ${ }^{28}$ Similar values have been reported for tumour tissue. ${ }^{16}$ Thus, over the entire measurement period the flooding procedure was successful in bringing the tissue and plasma free leucine enrichments to similar values.

A further consideration when measuring protein synthesis by taking liver biopsies at the time of surgery has been what effect, if any, the anaesthetic agents themselves would have on protein synthesis. This remains unknown in man, but we have investigated the effects of commonly used anaesthetic agents on tissue protein synthesis in the rat and found that although halothane causes a significant depression of liver protein synthesis, isoflurance did not have such an effect. ${ }^{29}{ }^{30} \mathrm{~A}$ standard anaesthetic regimen, using isoflurane, was therefore used in all patients in order to standardise and minimise any potential effect of anaesthetic drugs on liver protein synthesis.

The rate of liver protein synthesis in patients with non-metastatic colonic carcinoma reported here was not significantly different from the rate documented in patients with benign disease of the gastrointestinal tract. The rates obtained, however, are higher than those measured in five colorectal cancer patients by Stein et al, ${ }^{11}$ which was $13.4(2 \cdot 0) \% /$ day (mean (SEM)). Stein $e t a l^{11}$ used a constant infusion of $\left[{ }^{15} \mathrm{~N}\right]$ glycine which measures only intracellular proteins and not secretory proteins. The 'flooding dose' method, with its relatively short period of measurement, will measure both fixed and secretory protein synthesis. ${ }^{22}$ Different results may be explained by the 'flooding method' allowing a more accurate determination of the enrichment of those amino acids used for protein synthesis (a full discussion of the potential advantages and disadvantages of the 'flooding dose' technique for measuring tissue protein synthesis can be found in references ${ }^{14-17}$. The $\left[{ }^{15} \mathrm{~N}\right]$ is not distributed uniformly among the different amino acids, being largely confined to glycine, and the concentration of glycine in the free pool relative to the other amino acids is not only variable, but differs from that in protein. Thus, the enrichment of the total mixture of amino acids will be dependant on variations in the concentration of glycine, making the procedure unreliable. More recently, Fearon et $a l^{31}$ also estimated rates of liver protein synthesis by a constant infusion of $\left[{ }^{15} \mathrm{~N}\right]$ glycine, with measurement of the enrichment of free and protein bound glycine, in seven colorectal cancer patients with liver metastases. The rate was only $7 \cdot 5(0 \cdot 8) \% /$ day. The reasons for this difference may be partly explained by the different techniques of measurement. Also the presence of metastatic disease may have modulated protein synthesis by the non-affected hepatocytes, although further studies are needed to clarify this.

The rate of liver protein synthesis in patients with inflammatory bowel disease was $43 \%$ higher than the control group of patients. It is known that in inflammatory bowel disease the serum concentrations of acute phase reactants such as orosomucoid, alpha-1-acid glycoprotein, alpha1-antitrypsin and alpha-1-antichymotrypsin, are increased..$^{32-35}$ The increased rate of liver protein synthesis may therefore be explained, in part, by an increased synthesis of the acute phase reactants. Studies in experimental animals have shown a similar rise of liver protein synthesis during inflammation ${ }^{36}$ and after injection of endotoxin ${ }^{37}$ or recombinant cytokines. ${ }^{38}$ The relative contributions of the hepatocytes and cells of the reticuloendothelial cells to the increased rate of liver biopsy protein synthesis remains unknown, and further studies will be required to clarify this.

Could this increase in liver protein synthesis, however, account for the increase in whole body protein synthesis that Powell-Tuck et al reported in their series of patients? As for the colon, the contribution of liver to whole body protein synthesis in the absence of pathological conditions in man is unknown, but in the young rat the liver contributes only $13 \%$ of whole body protein synthesis. ${ }^{25}$ If similar figures were applied to man, then clearly an increase of only $43 \%$ in liver protein synthesis would not account for the reported increases in whole body protein synthesis. Therefore, protein synthesis in other, as yet unidentified, tissues must also have increased.

The results of these studies therefore provide further insight into the changes in protein metabolism, at the tissue level that occur in patients with gastrointestinal pathology. In addition, they extend the observations from whole body studies of protein metabolism that have been previously reported. The tissue biopsies in these studies are made up, not only of hepatocytes or colonic epithelial cells, however, but also comprise many other cell types - for example, reticuloendothelial cells, fibrous tissue. The tissue biopsy rate of protein synthesis is therefore a summation of that in all these cells. The further development of current techniques for measuring protein synthesis, in vivo, will be required to allow the contribution of each cell type to the rate of protein synthesis in the whole biopsy to be determined.

Rates of protein synthesis in tissues derived from colonic mucosa have been published in abstract form in the Proc Nutr Soc 1990 49: 135 .

We are grateful to Mr E Milne and Mr A G Calder for mass spectrometric analyses and to Mrs $\mathrm{V}$ Buchan for amino acid spectrometric analyses and to Mrs Scottish Hospitals Endowment Research Trust and Nestec Ltd, Scottish Hospitals Endow
for their financial support.

1 Brennan ME. Uncomplicated starvation versus cance cachexia. Cancer Res 1979; 37: 2359-64.

2 Dickinson RJ, Ashton MG, Axon ATR, Smith RC, Yeung CK, Hill GL. Controlled trial of intravenous hyperalimentation and total bowel rest as an adjunct to the routine treatment of acute colitis. Gastroenterology 1980; 79: 1199 204. 
3 Welch CS, Adams M, Wakefield EG. Metabolic studies in ulcerative colitis. $\mathcal{F}$ Clin Invest 1937; 16: 161-8

4 Herber D, Chlebowski RT, Ishbashi DE, Herrold JN, Block $\mathrm{JB}$. Abnormalities in glucose and protein metabolism in noncachectic lung cancer patients. Cancer Res 1982; 42: 4815-8.

5 Melville S, McNurlan MA, Calder AG, Garlick PJ. Increased protein turnover despite normal energy metabolism and responses to feeding in patients with lung cancer. Cancer Res 1990; 50: $1125-31$.

6 Herrmann VM, Garnick MB, Moore FD, Wilmore DW. Effect of cytotoxic agents on protein kinetics in patients with metastatic cancer. Surgery 1981; 90: 381-7.

7 Glass RE, Fern EB, Garlick PJ. Whole-body protein turnover before and after resection of colorectal tumours. Clin Sci 1983; 64: 101-8

8 Powell-Tuck J, Garlick PJ, Lennard-Jones JE, Waterlow JC. Rates of whole body protein synthesis and breakdown increase with the severity of inflammatory bowel disease. Gut 1984; 25: 460-4

9 Pain VM, Randall DP, Garlick PJ. Protein synthesis in liver and skeletal muscle of mice bearing an ascites tumour. Cancer Res 1984; 44: 1054-7.

10 Emery PW, Edwards RHT, Rennie MJ, Souhami RL, Halliday D. Protein synthesis in muscle measured in vivo in Halliday $D$. Protein synthesis in muscle measured in vivo

11 Stein TP, Mullen JL, Oram-Smith J, Rosato EF, Wallace HW, Hargrove WC. Relative rates of tumor normal gut, HW, Hargrove WC. Relative rates of tumor normal gut,
liver and fibrinogen protein synthesis in man. Am $\mathcal{F}$ Physiol 1978; 234: E648-52.

12 Mullen JL, Buzby GP, Gertner MH, Stein TP, Hargrove WC, Oram-Smith J, et al. Protein synthesis dynamics in human gastrointestinal malignancies. Surgery 1980; 87: 331-8.

13 Shaw JHF, Humberstone DA. Cancer: a metabolic parasite. Brf Surg 1988; 75: 1262.

14 Waterlow JC, Garlick PJ, Millward DJ. Protein tumover in mammalian tissues and in the whole body. Amsterdam: North Holland Publishing, 1978.

15 Garlick PJ, Wernerman J, McNurlan MA, Essen P, Lobley $\mathrm{GE}$, Milne $\mathrm{E}$, et al. Measurement of the rate of protein
synthesis in muscle of postabsorptive young men by synthesis in muscle of postabsorptive young men by
injection of a 'flooding dose' of $\left[1-{ }^{13} \mathrm{C}\right]$ leucine. Clin $\mathrm{S}$ ci 1989 ; injection of

16 Heys SD, Park KGM, McNurlan MA, Calder AG, Buchan V, Blessing $\mathrm{K}$, et al. In vivo measurement of tumour protein synthesis in human colorectal and breast cancer and its variability in separate biopsies from the same tumour. Clin Sci 1991; 80: 587-93.

17 McNurlan MA, Essen P, Heys SD, Buchan V, Garlick PJ, Wernerman J. Measurement of protein synthesis in human skeletal muscle: further investigation of the 'flooding' technique. Clin Sci 1991; 81: 557-64.

18 Calder AG, Smith A. Stable isotope ratio analysis of leucine and ketoisocaproic acid in blood plasma by gas chromatography/mass spectrometry. Use of tertiary chromatography/mass spectrometry. Use of tertiary
butyldimethylsilyl derivatives. Rapid Comms in Mass Spec butyldimethyl

19 MacKenzie SL, Tenaschuk D. Gas-liquid chromatography of $\mathrm{N}$-heptafluorobutyryl isobutyl esters of amino acids. f Chromatogr 1974; 97: 19-24.

20 Van slyke DD, Dillon RT, McFadyen DA, Hamilton P. Gasometric determination of carboxyl groups in free amino acids. F Biol Chem 1941; 141: 627-80.

21 Halliday D, Reid WWC. Mass spectrometric assay of stable isotope enrichment for the estimation of protein turnover in man. Proc Nutr Soc 1981; 40: 321-34.

22 McNurlan MA, Tomkins AM, Garlick PJ. The effect of starvation on the rate of protein synthesis in rat liver and small intestine. Biochem F 1979; 178: 373-9.

23 Heys SD, McNurlan MA, Park KGM, Milne E, Garlick PJ Baseline measurements for stable isotope studies; an alternative to biopsy. Biomed Environ Mass Spectrom 1990; 19 . 176-8.

24 Risio M, Coverlizza S, Ferrari A, Candelaresi GL, Rossini FP. Immunochemical study of epithelial cell proliferation in
hyperplastic polyps, adenomas, and adenocarcinomas of hyperplastic polyps, adenomas, and adenocarcin

25 McNurlan MA, Pain VM, Garlick PJ. Conditions that alte rates of tissue protein synthesis in vivo. Biochem Soc Tran 1980; 8: 283-5.

26 Powell-Tuck J. Protein metabolism in inflammatory bowe disease. Gut 1986; 27 (suppl): 67-71.

27 Bennet WM, Connacher AA, Scrimgeour CM, Smith K Rennie MJ. Increase in anterior tibialis muscle protein synthesis in healthy man during mixed amino acid infusion: studies of incorporation of $\left[11^{13} \mathrm{C}\right]$ leucine. Clin Sci 1989; 76: 447-54.

28 Ballmer PE, McNurlan MA, Milne E, Heys SD, Buchan V, Calder AG, et al. Measurement of albumin synthesis in man: new approach employing stable isotopes. Am $\mathcal{F}$ Physiol 1991: 259: E797-803.

29 Heys SD, Norton AC, Dundas CR, Ferguson K, Garlick PJ Anaesthetic agents and their effect on tissue protein synthesis in the rat. Clin Sci 1989; 77:651-5.

30 Ferguson K, Heys SD, Norton AC, Dundas CR, Garlick PJ. Effect of volatile anaesthetic agents on liver protein synthesis. Proc Nutr Soc 1990; 49: 182.

31 Fearon KCH, McMillan DC, Preston T, Winstanley $P$ Cruikshank AM, Shenkin A. Reduced rates of hepatic protein synthesis, the acute phase protein response, and protein syming in in advanced malignancy. Proc Nutr Soc 1990; 49: 167A.

32 Weeke B. Jarnum S. Serum concentrations of 19 serum proteins in Crohns disease and ulcerative colitis. Gut 1971; 12: 297-302.

33 Lubega J, Davies TJ. A comparison of serum mucoprotein with serum $\alpha \mathrm{l}$ acid glycoprotein, haptoglobin, and $\alpha$ l antitrypsin assays in monitoring inflammatory bowe disease. Clin Chim Acta 1990; 188: 59-70.

34 Buckell NA, Lennard-Jones JE, Hernandez MA, Kohn J, Riches PG, Wadsworth J. Measurement of serum protein during attacks of ulcerative colitis as a guide to patient management. Gut 1979; 20: 22-7.

35 Cooke WT, Fowler DI, Cox EV, Gaddie R, Meynell MJ. The clinical significance of orsomucoids in regional ileitis and ulcerative colitis. Gastroenterology 1958; 34: 910-9.

36 Ballmer PE, McNurlan MA, Southorn BG, Grant I, Garlick PJ. The effect of human interleukin-1 $\beta$ on liver protein synthesis in comparison to a systemic inflammatory insult synthesis in comparison to a systemic inflammatory insult induced $162 \mathrm{~A}$.

37 Jepson MJ, Pell J, Bates P, Millward DJ. The effects of ndotoxaemia on protein melism in ske letal muscle and liver of fed and fasted rats. Biochem $\mathcal{F}$ 1986; 235: 329-36.

38 Charters Y, Grimble RF. Effect of recombinant human tumour necrosis factor $\alpha$ on protein synthesis in liver, 